European Journal of Pragmatism and American Philosophy

VII-2 | 2015

John Dewey's Lectures in Social and Political Philosophy (China)

\title{
The Realist Challenge to Conceptual Pragmatism
}

\section{Peter Olen}

\section{OpenEdition}

\section{Journals}

Electronic version

URL: http://journals.openedition.org/ejpap/413

DOI: 10.4000/ejpap.413

ISSN: 2036-4091

Publisher

Associazione Pragma

\section{Electronic reference}

Peter Olen, «The Realist Challenge to Conceptual Pragmatism », European Journal of Pragmatism and American Philosophy [Online], VII-2 | 2015, Online since 23 December 2015, connection on 30 April 2019. URL : http://journals.openedition.org/ejpap/413 ; DOI : 10.4000/ejpap.413

This text was automatically generated on 30 April 2019.

\section{(c)}

Author retains copyright and grants the European Journal of Pragmatism and American Philosophy right of first publication with the work simultaneously licensed under a Creative Commons AttributionNonCommercial-NoDerivatives 4.0 International License. 


\title{
The Realist Challenge to Conceptual Pragmatism
}

\author{
Peter Olen
}

\section{Introduction}

1 When looking back at debates between American realist and pragmatist philosophers, Wilfrid Sellars occupies a problematic place in the canon. Raised by one of the most prominent critical realist of the early 20th century, W. Sellars spent most of his career espousing a form of scientific realism. ${ }^{1}$ Despite Roy Wood Sellars' anti-pragmatist orientation and explicit arguments against John Dewey, C. I. Lewis, and other pragmatists, there has been increased interest in placing W. Sellars, both historically and thematically, within the pragmatist tradition. ${ }^{2}$ Even though R.W. Sellars depicted critical realism as opposed to pragmatism, this does not mean that $\mathrm{W}$. Sellars followed suit. It could be the case that son, unlike father, gravitated towards pragmatic philosophers or themes despite his father's misgivings. Nonetheless, W. Sellars' various discussions of critical realism seem to exhibit more than mere family resemblance. One fruitful question to ask might be this: if we take his endorsement of critical realism seriously, why should we place W. Sellars within the pragmatist tradition?

2 The point of this paper is to discuss R.W. Sellars' challenges to pragmatism, as embodied by Lewis's form of "conceptual pragmatism," in an effort to both trace where the two camps diverge and locate W. Sellars somewhere in the debate. By discussing R. W. Sellars' criticisms of pragmatism, which center on issues surrounding immediate experience, perception, and meaning, we get a clearer picture of W. Sellars' relationship to the pragmatist tradition. I conclude by arguing that R. W. Sellars' critiques of the given and meaning are the same critiques offered by W. Sellars in the 1950s, and that recent attempts to place $\mathrm{W}$. Sellars within the pragmatist tradition have largely ignored this line of influence. 
Of course, much of this argument turns on exactly what is meant by the "pragmatist tradition.' As Rebecca Kukla and Mark Lance have noted:

There are two large camps of philosophers who fly by the banner of pragmatism. [...

] First, there are philosopher who find their roots in the classic American Pragmatist such as Dewey, James, and Peirce, and often also in the early work of Heidegger and his French successors such as Pierre Bourdieu and Maurice MerleauPonty. [...] Second, there is what we might call "Pittsburgh School Pragmatism." [...] These philosophers are committed to the principle that the best place from which to begin thinking about intentional phenomena such as meaningful speech acts and contentful mental states is with our practical interactions with the world and with others, and their normative structure. (Kukla \& Lance 2009: 3-4)

W. Sellars is clearly committed to, and the founder of, the latter sense of pragmatism, the kind that emphasizes our practical interactions and their normative structure as the starting point for philosophy. Classifying W. Sellars as a pragmatist in this sense is, at least for my purposes, unproblematic. Yet such concerns are not generally indicative of the kind of classic pragmatism found in the tradition that stretches from C. S. Peirce to C. I. Lewis. It is within the classic form of pragmatism that some commentators have placed W. Sellars. This historical classification is what I aim to correct.

This is not to say that thematic discussions of common themes are barred from connecting philosophers previously thought unrelated. There could be substantial philosophical value in picking out the commonalities between philosophers who embrace similar or the same ideas in all of their variations and differing incarnations. I am not arguing against thematic accounts of Charles Sanders Peirce's and William James's writings on language, for example, that connect some of their ideas with those found in the later Wittgenstein; there could be - for all I know - something profitable in reinterpreting Wittgenstein's ideas in light of Peirce's and James's philosophies. My main concern is with what I take to be the subtle confusion of thematic accounts for historical claims. $^{3}$ As a quick distinction, we might classify thematic claims as those that claim a relationship between figures or ideas on the basis of similarity of content, while historical claims concern the actual influence and motivations behind a given figure's views. While the difference between the two kinds of claims might initially seem clear enough, there is a tendency to confuse thematic connections as somehow licensing historical claims about the connection or 'progression' of ideas. Even if classifying W. Sellars as a pragmatist makes thematic sense, this does not mean that, historically speaking, the chronological succession of W. Sellars to classical pragmatism entails that it played an influential role in the development of his philosophy.

\section{Critical Realism and Pragmatism}

6 Although the later works of W. Sellars, specifically the Sellars one finds in Science and Metaphysics, is willing to concede some ground to the pragmatist tradition, I am primarily concerned with W. Sellars' work leading up to the publication of Science and Metaphysics in 1968. When reflecting back on the early parts of his career, W. Sellars claimed that:

When I was coming to philosophical consciousness, the great battles between the systems which began the Twentieth Century were drawing to a close, although the lightning and the thunder were still impressive. I cut my teeth on issues dividing Idealist and Realist and, indeed, the various competing forms of upstart Realism. I saw them at the beginning through my father's eyes, and perhaps for that reason never got into Pragmatism. He regarded it as shifty, ambiguous, and indecisive. One 
thinks in this connection of Lovejoy's "thirteen varieties," though that, my father thought, would make too tidy a picture. [...] Pragmatism seemed all method and no results.

After striking out on my own, I spent my early years fighting in the war against Positivism - the last of the great metaphysical systems; always a realist, flirting with Oxford Aristotelianism, Platonism, Intuitionism, but somehow convinced, at the back of my mind, that something very much like Critical Realism and Evolutionary Naturalism was true.

Thus it wasn't until my thought began to crystallize that I really encountered Dewey and began to study him. [...] He caught me at a time when I was moving away from "the Myth of the Given" (antecedent reality?) and rediscovering the coherence theory of meaning. Thus it was Dewey's Idealistic background which intrigued me the most. I found similar theme Royce and later in Peirce. I was astonished at what I had missed. (Sellars 1979: 7; emphasis added)

7 Not surprisingly, Sellars' initial philosophical orientation was guided by his father's critical realism, though it would be going too far to claim that pragmatism held no interest for W. Sellars. Sellars' comment that he came to recognize the importance of Dewey's philosophy when moving away from the myth of the given places this reference sometime in the late 1940s, ${ }^{4}$ yet whatever engagement the early Sellars had with pragmatism is not readily apparent in his earliest publications ${ }^{5}$ and was filtered through the lens of critical realism. When W. Sellars did turn his attention to pragmatism, it was the "idealistic background" of Dewey that attracted his attention.

While various issues divide critical realism and pragmatism, the most apparent influence on W. Sellars are debates between R.W. Sellars and Lewis over the proper analysis of perception and immediate awareness. A guiding commitment of both R.W. Sellars and $W$. Sellars is the idea that perception is an inherently mediated practice, one that does not presuppose immediate awareness of 'bare' presentations of sense. From the standpoint of critical realism, "perceptual knowing has its categories and is not the simple flux of sense-data and images which extreme empiricism wished to reduce it to" (Sellars 1932: 139). That is, "in even the elementary level of knowing called perceiving, the human mind is operating in terms of meaning and distinctions" (Sellars 1932: 69). What is indicative of perception is that it is a "thinking of things" are not simply a matter of bare receptivity.

This analysis does not amount to an outright rejection of receptivity; perception is mediated by sensations, though such sensations "are not the objects of perceiving but one means of perceiving" (Sellars 1932: 59). Even if sensing and sensation are constitutive aspects of knowing, it is only a naive form of realism that assumes what is known are primarily sensations and not objects. Perception, whether it leads to knowledge or 'simple' awareness, always presupposes categorical structure; it involves "denotative intent and a disclosure claim. What I mean by a disclosure-claim is a thinking an object in terms of predicates." (Sellars 1932: 75). According to R.W. Sellars, the problem with traditional empiricist approaches to perception is the confusion of the intentional nature of thought with the receptivity found in sensible experience. For both R.W. Sellars and W. Sellars, it is a confusion of the 'aboutness' of thought with the idea that sensations are, in some sense, 'information-carrying.' ${ }^{6}$

10 The critical realist turn is found in a conception of sensations as mediating entities, ones through which we gain knowledge of material objects and the external world. Perception yields knowledge or awareness of "independent and enduring things" and not just sensory presentations (Sellars 1932: 146). Mistakenly assuming that sensory experience 
yields knowledge of mere presentations or sensations, though not objects, leads to a rejection of what R.W. Sellars calls the "metaphysical veracity" of our perceptual abilities. That is, perception discloses the external world in such a way that epistemological considerations entail metaphysical commitments about the objective existence of the external world. Thus, our experience of seeing a slowly crawling sloth in our visual field should, ceteris paribus, lead to the knowledge or awareness of a real, slowly crawling sloth in the world.

11 R. W. Sellars' commitment to the metaphysical veracity of our perceptions is contrasted with Lewis's explicit dismissal of the idea. For the Lewis-styled pragmatist, one starts from the pragmatic significance of experience, the fact that our perceptual apprehensions are significant insofar as they function in the "guidance of our actions and anticipation" of future consequences (Lewis1946: 16). The knowledge of an objective external world holds metaphysical significance, if it holds any significance at all, as derivative from the pragmatic significance of given elements in experience (Lewis 1946: 16). The given elements of our experience simply yield conditional knowledge of actual and possible future experience. Even though such conditional knowledge is available for continued verification in our experience, it does not entail a metaphysical commitment to an objectively existing world. Thus, the experience of seeing a slowly crawling sloth, for example, might give us reason to expect the continued presence of the sloth in our visual field, but such experience and expectations do not entail that a slowly crawling sloth exists independent of our experience of it (simply that we ought to anticipate the continued visual sensation of a slowly crawling sloth).

R. W. Sellars' critique of Lewis is not a general indictment of pragmatism as a movement insofar as pragmatism is willing to abandon its commitment to a problematic form of "extreme" empiricism (in favor, of course, of the metaphysical commitments and analysis of perception found in critical realism), it could be seen as a promising road to naturalism (Sellars 1932: 134). Yet Lewis's version of pragmatism is interpreted by R. W. Sellars as inextricably wed to extreme empiricism, one which rejects anything like the existence of an external world and embraces a kind of Kantian approach to "constructing" the world out of phenomenal presentations of sense (Sellars 1932: 51). What is experienced are not objects or properties of objects, but sensations, appearances, or presentations. Although immediate awareness of the given elements in experience may not constitute knowledge of objects in an external world, our knowledge of objects are "built-up" from the interpretation or categorization of such experience (Lewis 1929: 37-8).

Lewis's insistence on the given element in experience is interpreted by R. W. Sellars as a "logical development of the tradition of immediate perception" that is found in William James's form of pragmatism, but stretches back to Locke and Berkeley (Sellars 1968: 299). Even though some of Lewis's claims sound realistic, ${ }^{7}$ his contention that immediate experience constitutes a form of perceptual knowledge commits him to the aforementioned problematic form of empiricism:

Some twelve years ago in a chapter I contributed to the book, Philosophy for the Future, I pointed out how realistic Lewis could sound. He affirms that we knew through and by means of presentations some objective thing or event. Is he, like Dewey, a naive realist with pragmatic intent or a phenomenalist? But I have the conviction that he regards these presentations as constituents of the object known. This fits in with 'immediate perception' and the rejection of critical realism. (Sellars 1968: 304) 

immediate sensory presentations or appearances as knowledge, that R.W. Sellars finds problematic. To classify sensory presentations in such a constitutive role locates Lewis in a Kantian/phenomenalist strand of thought that critical realism explicitly rejects. epistemology is an almost categorically misunderstood phenomena. As early as 1929 , Lewis explicitly claims that it is objects, and not phenomenal presentations of sense, that we experience:

It is indeed the thick experience of the world of things, not the thin given of immediacy, which constitutes the datum of philosophical reflection. We do not see patches of color, but trees and houses; we hear, not indescribable sound, but voices and violins. What we most certainly know are objects and full-bodied facts about them which could be stated in propositions. [...] Any Kantian "manifold" as a psychic datum or moment of experience, is probably a fiction, and the assumption of it as such is a methodological error. (Lewis 1929: 54-5) abstraction" or "fiction" from our actual experience of the world (Lewis 1929: 54). Even though Lewis's later works (especially Analysis of Knowledge and Valuation) discuss our knowledge of objects in terms of actual and possible experiences, he argues that "there is nothing in this character of knowledge or in any consideration pertinent to it which justly should suggest that our knowledge, though partial, is not, so far as it extends, $a$ knowledge of existents as they are in themselves" (Lewis 1955: 347; emphasis added).

Even if R. W. Sellars radically misinterpreted conceptual pragmatism, ${ }^{8}$ the fact that this is a misinterpretation makes no difference when exploring W. Sellars' placement in the history of philosophy. What matters in this case is not whether Lewis's position has been accurately depicted as a form of realism or phenomenalism, but whether R. W. Sellars and W. Sellars understood pragmatism as wed to a problematic form of phenomenalism. And in this sense, both R. W. Sellars and W. Sellars are in agreement - conceptual pragmatism remains opposed to critical realism insofar as it presupposes a problematic epistemology. Even though this may be a misinterpretation of conceptual pragmatism, it is one held by both R. W. and W. Sellars. ${ }^{9}$

\section{Wilfrid Sellars}

W. Sellars explicated and endorsed his father's position in 1954, mounting some of the same arguments against pragmatism, at least what was interpreted as Lewis's form of pragmatism, as found in R.W. Sellars' criticisms of Lewis. Thus, when characterizing his (and his father's) realism, W. Sellars claims that

Perhaps the most useful answer is in terms of its contrast with 'radical empiricism.' For the approach of the naturalistic realist to the problems of knowledge and meaning is as unlike that of radical empiricism as an approach can be without renouncing all claim to the term 'empiricism.' And, indeed, we find that in The Philosophy of Physical Realism, my father points to the radical empiricism of C. I. Lewis as the most challenging formulation of the anti-realistic point of view. (Sellars 1954: 27)

W. Sellars goes significantly further than his father in diagnosing the ills of pragmatism as embodied in Lewis's epistemology. The issue is not just that pragmatists mistakenly connect perception with immediate awareness, but that this connection leads directly to 
a naive understanding of concepts and concept formation. The connection between immediate awareness and meaning leads pragmatists to claim that concepts are, in some sense, 'about' patterns of sensation or possible future experiences (Sellars 1954: 29). To grant the connection between immediate awareness and meaning is to mistake thinking that "common sense concepts of seeing a color, hearing a sound, or feeling a pain are concepts of sensuous immediacy" (Sellars 1954: 29). Indicative of his endorsement of critical realism, W. Sellars claims that perception is defined by the categorized, intentional awareness of objects and not patterns of sensation. The kind of Lockean empiricism that requires concepts to be 'built-up' from sensory patterns of awareness is de facto ruled-out on realistic grounds and such an empiricism, as indicated by the passage above, is explicitly connected to Lewis's pragmatism in both father's and son's accounts of perception.

Thus, one finds W. Sellars endorsing the main thesis of critical realism contra empiricism:

Thus, when Jones sees a chair, although his 'perceptual experience' is founded on, guided, and controlled by his sensations, there is nothing in the nature of aboutness or reference which requires us to say that his 'experience is primarily about the sensations, and only about the chair in some more complicated or derived sense of 'about.' His perception is 'mediated by' the sensations, but his perception is not about the sensations. (Sellars 1954: 20)

This endorsement comes to fruition two years later in "Empiricism and the Philosophy of Mind" (hereafter EPM) where W. Sellars charges sense data theorists with the mistake of treating the occurrence of sensations as a cognitive or epistemic fact. Reminiscent of his father's wording, W. Sellars argues that this is the mistake of assimilating "'having a sensation of a red triangle' to 'thinking of a celestial city' and to attribute to the former the epistemic character, the 'intentionality' of the latter" as one key instance in the myth of the given (Sellars 1956: 211).

The earlier point surrounding disagreements between critical realism and pragmatism foreshadow W. Sellars' objections to traditional empiricism and foundationalism in EPM. Although some $\mathrm{e}^{10}$ have suggested that Lewis is the primary target of $\mathrm{W}$. Sellars' objections to sense data theorist and giveness in EPM, this is too myopic of a reading. Lewis's later philosophy, as found in Analysis of Knowledge and Valuation, side-steps many of the early objections to sense data theory discussed by W. Sellars. It could be that Lewis's later epistemology avoids connecting immediate awareness and knowledge in the way criticized by R. W. Sellars in the 1930s. Even if this is the case, such a change does not settle the earlier dispute between critical realism and pragmatism or somehow correct the misinterpretation present in both R. W. Sellars and W. Sellars.

That being said, it is just as problematic to claim that W. Sellars' anti-foundationalist arguments do not target, at least in part, the kind of empiricism that he read into traditional pragmatism. One finds this kind of reading in Misak:

Sellars explodes the myth of the given. He argues that there are no basic or pure kinds of knowledge - a belief can only be justified by another belief. Moreover, all beliefs have an inescapably conceptual element. To grasp even something as simple as a triangle requires the concept of triangle so that one can classify it as such. To become aware of something in the first place is to respond to it by applying a concept. Awareness - all of it - 'is a linguistic affair.' We have seen this very thought in Peirce, Lewis, and every other pragmatist. (Misak 2013: 221-2; emphasis added) 

given, but that W. Sellars, insofar as he engages with either Peirce or Lewis, interpreted them this way. ${ }^{11}$ Even if every classical pragmatist endorsed the kind of conceptualism suggested by Misak, both R. W. Sellars and W. Sellars didn't see what would have been a point of philosophical kinship. More so, it is not clear why a corrected reading of pragmatism's history - one that depicts pragmatism as inherently against the myth of the given - would somehow change W. Sellars' early misunderstanding of these points and, thus, his subsequent historical placement. Exactly how W. Sellars understood pragmatism (and, thus, how much of a role it played in motivating his early arguments) is the historically relevant factor.

This last point is crucial if we want to establish a historically sound connection between $\mathrm{W}$. Sellars and the pragmatist tradition, but there is all the difference in the world between pragmatists' rejection of giveness and W. Sellars' recognition of this fact. While some pragmatists may have rejected giveness in some or all of its forms, it by no means follows that W. Sellars' rejection of giveness was motivated by this particular tradition or that he was aware of this fact while constructing his own arguments against giveness. One could concede this point and thematically classify W. Sellars as a pragmatist, but this is not what Misak is claiming when she connects W. Sellars' arguments against giveness with "Peirce, Lewis, and every other pragmatist." Instead, she is making a historical claim about the actual antecedent causes and motivations behind W. Sellars' rejection of giveness.

Clarifying ${ }^{12}$ this aspect of the philosophical relationship between R.W. Sellars and W. Sellars casts prima facie doubt on the idea that W. Sellars inherited his objections to giveness from the pragmatist tradition. Although Misak and Richard Shusterman, for example, are correct that some pragmatist are fairly hostile to the idea of unmediated perception as a form of knowledge, W. Sellars' rejection of giveness is inherited, at least in part, from critical realism and not pragmatism. Even if W. Sellars' rejection of giveness and various pragmatists' commitments against the immediacy of sense data line up perfectly well, this does not prove that W. Sellars was aware of that fact in the 1940s-1950s (the period where he was refining his arguments against giveness). If Peirce and Dewey held commitments consistent with the critical realists' commitments against unmediated awareness, this fact falls short of giving us a historical connection between traditional pragmatism and W. Sellars' rejection of giveness. This point becomes explicit at the end of W. Sellars' analysis of critical realism:

I would go further and say that only a philosophy which, like Physical Realism, has abandoned the dead end road of immediacy, while yet maintaining a broadly empirical orientation, can hope to combine a coherence theory of meaning ('a concept is an intersection in a network of implications') with the empiricist's contention that it is always proper to ask for an 'inductive' justification of any proposal to revise the framework of law-like sentences (and, hence, of meanings) in terms of which we approach our environment. (Sellars 1954: 31-2)

The solution to puzzling out perception and immediate awareness is found in a form of realism diametrically opposed to the kind of empiricism attributed to Lewis. Insofar as one is wed to a close relationship between immediacy and meaning, (the relationship both R. W. Sellars and W. Sellars argue characterizes pragmatism), then one cannot truly reject giveness and foundationalism. 
What ties together R.W. Sellars' and W. Sellars' interpretation of pragmatism is the equating of a pragmatist treatment of perception and knowledge with a fairly radical form of empiricism. While pragmatism deserves credit for moving philosophy away from 19th century versions of sensationalism and absolute idealism, both R.W. Sellars and W. Sellars understand pragmatism - at least the version of pragmatism they found in Lewis's philosophy - as inextricably tied to problematical empiricist commitments that ostensibly replaced those movements. Even if this is the wrong interpretation of pragmatism (as Misak and others might rightly argue), and even if there is no necessary connection between pragmatism and this kind of empiricism, the issue is whether W. Sellars saw the connection as embodied in pragmatist epistemology qua Lewis. Since we are essentially picking out the motivation behind W. Sellars' arguments, it stands to reason that how he understood pragmatism (in this case) is a large determiner of how influential pragmatism actually was in helping form his positions. Of course, this reading of Lewis could be wrong - Murray Murphey ${ }_{13}^{13}$ for one, provides strong arguments against this reading of Lewis. Since we are concerned with the historical W. Sellars, both as he interpreted the relative intellectual movements around himself and as we should place him within his historical context, it is difficult, even inaccurate, to separate pragmatism ( qua Lewis) from a problematic form of empiricism. ${ }^{14}$

\section{Further Considerations}

Even if W. Sellars sides with critical realism over pragmatism, one could argue there are additional, stronger connections that justify placing W. Sellars within the pragmatist tradition. One could claim, for example, that W. Sellars' early ${ }^{15}$ arguments for the necessity of material rules of inference are indicative of pragmatism, but this simply equivocates on the differing senses of 'pragmatism' I discussed earlier, confusing classic pragmatism with a broad interest in pragmatics qua linguistic practices. ${ }^{16}$ As early as 1949 , one can find W. Sellars referencing linguistic practices and material rules of inference as distinct from formal notions of inference and language, but these points are not offered as a defense or endorsement of pragmatism, but as an indictment of logical positivism. ${ }^{17} \mathrm{~W}$. Sellars' early emphasis on pragmatics turns on a complicated debate between positivists and realists over interpretations of Rudolf Carnap's philosophy, ${ }^{18}$ but it does not make substantive contact with pragmatism.

Bernstein and Misak are two of the most recent philosopher to claim W. Sellars as part of the pragmatist tradition. While admitting that W. Sellars inherited much of his father's philosophical commitments and attitudes, Misak claims that "there can be no doubt that Sellars belongs to the pragmatist tradition" (Misak 2013: 223). Her evidence for this is found in three main sources: W. Sellars' reliance on supposedly pragmatist notions (at least notions traced to pragmatist origins), his early discussion of pragmatist accounts of language and behavior, and his later theory of truth. Although I have no qualms with Misak's claims about Sellars' later views on truth per se, there are strong reasons to doubt her characterization of W. Sellars' early writings.

31 Misak is right to claim that W. Sellars uses the type/token distinction (starting in his earliest publication), but it is hasty to read this as a direct influence from Peirce to W. Sellars (Misak 2013: 218). When W. Sellars credits Peirce with the type/token distinction, there is no further exploration of the connection between his own philosophy and Peirce's work, no discussion of pragmatism and its approach to language, no adoption 
of explicitly pragmatist commitments, and no discussion of Peirce's own philosophy. Misak is right to point out this connection, but there is not a substantive relationship to be found between W. Sellars' employment of the type/token distinction and any aspect of Peirce's philosophy. Even when W. Sellars does mention Peirce or Peirecian terminology, one could just as easily connect W. Sellars' distinction between expressions types and tokens with Carnap's distinction between sign designs and sign events.

Insofar as we are looking for a specifically pragmatist antecedent for W. Sellars' reasoning about pragmatic (as opposed to pragmatist) treatments of language, a more proximate source could be Charles Morris's early writings (Morris 1938; Morris 1946). Morris's work, especially his later publications, represents a direct connection between behavioristic treatments of language and norms, and the pragmatist tradition. Unfortunately, W. Sellars explicitly rejects Morris's framework as "too psychologistic" when discussing the then-recent publication of Signs, Language, and Behavior with his father (Sellars 1948). What helps usher W. Sellars' early publications from a 'formal' conception of philosophy to one that embraces this kind of behavioral-pragmatic language is more likely to be found in W. Sellars' endorsement of behaviorism, not pragmatism. ${ }^{19}$

There is support for the idea that W. Sellars belongs in the pragmatist tradition; W. Sellars' early praising of Dewey's rejection of giveness, for example, might be read as W. Sellars identifying rationalist alternatives to empiricism with pragmatism (though, as we have seen, this is not the case). Crediting what he calls "the more sophisticated forms of pragmatism," W. Sellars claims that the linguistic rules that characterize behavior must be decided pragmatically (Sellars 1949: 134). But it is important to keep in mind that most of these observations are made in the context of correcting what W. Sellars saw as an overly descriptivist or scientistic strand of thinking in traditional pragmatism:

But if I do not accuse the pragmatist as being a descriptivist as a matter of principle, I do contend that pragmatism has been characterized by a descriptivistic bias. Thus, while it has defended the important insight that to reject descriptivism in the philosophy of mathematics is not to embrace rationalism, it has committed itself to descriptivism in other areas of philosophy (e.g., in its interpretation of truth and moral obligation) with all the fervor of a Dutch boy defending the fertile lands of Naturalism against a threatening rationalistic flood. Now it will be my contention in this paper that a sound pragmatism must reject descriptivism in all areas of philosophy. (Sellars 1949: 118-9)

While there is some commonality between W. Sellars and some pragmatists, what I have been arguing is that, historically speaking, thinking of W. Sellars as 'essentially pragmatist' is too narrow of a reading to be historically accurate. There are, somewhat clearly, shared sympathies and pragmatist themes that run through W. Sellars' publications.

This kind of 'corrective' reading of pragmatism is also found in W. Sellars' short discussion of pragmatism in "Some Reflections on Language Games":

Now I would argue that Pragmatism, with its stress on language (or the conceptual) as an instrument, has had hold of a most important insight - an insight, however, which the pragmatist has tended to misconceive as an analysis of 'means' and 'is true.' For it is a category mistake (in Ryle's useful terminology) to offer a definition of 'S means $\mathrm{p}$ ' or ' $\mathrm{S}$ is true' in terms of the role of $\mathrm{S}$ as an instrument in problem solving behavior. On the other hand, if the pragmatist's claim is reformulated as the thesis that the language we use has a much more intimate connection with conduct than we have yet suggested, and that this connection is intrinsic to its structure as language, rather than a "use" to which it "happens" to be put, then Pragmatism 
assumes its proper stature as a revolutionary step in Western philosophy. (Sellars 1954/1963: 324; emphasis added)

\section{thematic ${ }^{20}$ account of philosophy, one that eschews the importance of historical connections between classic pragmatist and contemporary philosophers. Bernstein} claims, for example, that

When Rorty reads the later Wittgenstein, Quine, Sellars, and Davidson as furthering the pragmatist agenda, or when Putnam raises the question "Was Wittgenstein a Pragmatist?," neither is suggesting that the achievements of these philosophers are the result of direct influence of the classical pragmatists. [...] My fundamental point is that philosophers, starting from the most diverse orientations and without being directly influenced by the classical pragmatists, have been articulating insights and developing theses that are not only congenial with a pragmatic orientation but also refine its philosophical import. (Bernstein 2010:14-5)

Even if, thematically speaking, Bernstein is correct about the irrelevancy of the historical connection, it would make a difference when there are competing origin stories for contemporary pragmatic themes (i.e., historical accounts matter if there are competing, yet equally plausible, historical antecedents). If classical pragmatism was the only plausible source for such ideas, despite the fact that a clear historical connection could not be drawn between W. Sellars and the classic pragmatists, then Bernstein's emphasis on the adoption and refinement of pragmatic theses would be an invaluable explanation. If the juxtaposition of critical realism with conceptual pragmatism I presented above is 
correct, then there is at least one viable, if not more historically plausible, source for W. Sellars' views. ${ }^{21}$

While the thematically-based depiction of diverse philosophers converging on themes anticipated by the classic pragmatists is compelling, such a placement is simply not a historical one. Unless we are unnecessarily committed to a hardline historicist approach to philosophy (i.e., one claiming that anything but a historically and contextuallygrounded account of philosophy is, at best, misleadingly anachronistic), we need not think that a historically-grounded account is the only acceptable characterization of philosophy. Yet, this kind of conceptual parsing only works if we clearly demarcate historical from thematic characterizations of philosophy. In the same breath that he is willing to claim no historical connection need exist between classical pragmatists and contemporary philosophers, Bernstein also argues that Rorty's placement of contemporary analytic philosophers in conversation with the classical pragmatists, for example, does much to challenge "the standard narrative of the development of twentieth-century philosophy in America" (Bernstein 2010: 14). But how is this not a straightforwardly historical claim? Bernstein's characterization of pragmatism simply cannot come from both directions. He is either offering a historical account of pragmatism's legacy, one that stretches unbroken from the 19th century until today, or he is not. If not, then his thematic account of pragmatic ideas cannot 'correct' or 'challenge' historical narratives because, quite frankly, there is no reason to think thematic accounts are making or impacting historical claims. Such an account could be understood as offering an interesting comparative story of differing reactions to a common theme, but this is a far different claim than any historically sensitive account of a given time period.

None of this entails that the pendulum should swing too far the other direction. Surely it would be wrong to claim that pragmatism plays no influential role in W. Sellars' philosophical development, although I fail to see how such claims clarify his philosophical allegiances unless they appear alongside a carefully articulated historical context. Although there might be strong thematic reasons to group W. Sellars' philosophy (e.g., his social articulation of reason, his later adoption of a form of warranted assertability, his rejection of giveness) within the pragmatist tradition, this is a wholly distinct concern from any specifically historical connection between W. Sellars and pragmatism. As I stated in the beginning of this paper, I do not think that we need to deny the importance of thematic accounts, we just need to ensure that such accounts are clearly separated from historical accounts.

Another reaction to recent attempts to "pragmatize" W. Sellars might be to point out the underwhelming amount of literature on the role of new and critical realism in early 20th century American philosophy. W. Sellars might seem like such a prime candidate for placement within the pragmatist tradition precisely because discussion of new and critical realism has been almost completely absent since the early $1930 \mathrm{~s} .{ }^{22}$ The issue is not that, conceptually speaking, realism and pragmatism are necessarily incompatible. The problem is that R.W. Sellars and W. Sellars (at least the early W. Sellars) understood pragmatism and realism as incompatible paths to naturalism. W. Sellars was a notorious system-builder, more than willing to appropriate what he saw as the correct aspects of various, sometimes competing philosophical traditions. There are numerous interpretations one might give of W. Sellars as rationalist, empiricist, positivist, 
pragmatist, or realist. None of them, if taken singularly, would do justice to the systematic and multi-dimensional character of W. Sellars' thought.

\section{BIBLIOGRAPHY}

BERNSTEIn R., (2010), The Pragmatic Turn, Cambridge, Polity Press.

HARLOW V., (1931), A Bibliography and Genetic Study of American Realism, Oklahoma City, Harlow Publishing Company.

KUKLA R. \& M. LANCE, (2009), 'Yo!' and 'Lo!' The Pragmatic Topography of the Space of Reasons, Cambridge, Harvard University Press.

KUKLICK B., (2001), A History of Philosophy in America: 1720-2000, Oxford, Oxford University Press. LEWIS C. I., (1929), Mind and the World Order: Outline of a Theory of Knowledge, New York, Dover Publications.

LEWIS C. I., (1946), An Analysis of Knowledge and Valuation, La Salle, Open Court Press.

LEWIS C. I., (1955), "Realism or Phenomenalism?," in The Collected Papers of Clarence Irving Lewis, Stanford, Stanford University Press, 1970.

MISAK C., (2013), The American Pragmatists, Oxford, Oxford University Press.

MORRIS C., (1938), Foundations of the Theory of Signs, Chicago, University of Chicago Press.

MORRIS C., (1946), Signs, Language, and Behavior, New York, Prentice-Hall Inc.

MURPHEY M., (2005), C. I. Lewis: The Last Great Pragmatist, Albany, SUNY Press.

OLEN P., (2016), Wilfrid Sellars and the Foundations of Normativity, London, Palgrave Macmillan.

OLEN P., (forthcoming), “A Forgotten Strand of Reception History: Understanding Pure Semantics," Synthese.

PRICHARD H. A., (1938), “The Sense-datum Fallacy,” Proceedings of the Aristotelian Society (Supplementary Volume) 17, 1-18.

SACHS C., (2014), Intentionality and the Myths of the Given: Between Pragmatism and Phenomenology, London, Pickering and Chatto.

SELLARS R. W., (1932), The Philosophy of Physical Realism, New York, The Macmillan Company.

SELLARS R. W., (1968), "In Defense of Metaphysical Veracity," in P. A. Schilpp, ed., The Philosophy of C. I. Lewis, La Salle, Open Court Press.

SELLARS W., (1948), 1948 Letter to Roy Wood Sellars. Wilfrid S. Sellars Papers, 1899-1990, ASP.1991.01, Archives of Scientific Philosophy, Special Collections Department, University of Pittsburgh. SELLARS W., (1949/2005), "Language, Rules and Behavior," in J. Sicha, ed., Pure Pragmatics and Possible Worlds: The Early Essays of Wilfrid Sellars, Atascadero, Ridgeview Publishing Company. 
SELLARS W., (1953/1963), “Is there a Synthetic A Priori?," Science, Perception, and Reality,

Atascadero, Ridgeview Publishing Company.

SELLARs W., (1954), "Physical Realism," Philosophy and Phenomenological Research 15, 13-32.

SELLARS W., (1954/1963), “Some Reflections on Language Games," Science, Perception, and Reality, Atascadero, Ridgeview Publishing Company.

SELLARs W., (1956/2000), "Empiricism and the Philosophy of Mind," in W. deVries \& T. Triplett, eds., Knowledge, Mind, and the Given: Reading Wilfrid Sellars" "Empiricism and the Philosophy of Mind," Indianapolis, Hackett Publishing Company.

SELLARS W., (1967/1992), Science and Metaphysics: Variations on Kantian Themes, Atascadero,

Ridgeview Publishing Company.

SELLARs W., (1979), Naturalism and Ontology, Reseda, Ridgeview Publishing Company.

SHUSterman R., (1997), Practicing Philosophy: Pragmatism and the Philosophical Life, New York, Routledge.

\section{NOTES}

1. Whether scientific realism is necessarily opposed to pragmatism is debatable. The important point here is the acknowledgement of W. Sellars as being, in some sense, a realist by way of general orientation.

2. This is not to say that all pragmatists claim W. Sellars as one of their own. Richard Shusterman, for example, has argued that W. Sellars' indictment of the given makes him hostile towards a Deweyan conception of experience. See Shusterman 1997.

3. Mason Cash, in an unrelated context, gave one of the best examples of the reasoning behind conflating historical and thematic claims. Paraphrasing from one of his lectures: we might think that if we squint hard enough, the atoms that make up that wall over there kind of look like a toaster. But they are, in fact, not a toaster. So what difference does it make that the arrangement of atoms happen to look like a toaster?

4. Sellars makes overtures to both of these points as early as 1947, but explicitly credits Dewey in Sellars 1949.

5. Even though W. Sellars' initial publications focused on developing a pure account of pragmatics, the pragmatist tradition is not a factor in W. Sellars' 'pure pragmatics' papers. See Olen forthcoming and Olen 2016, especially chapter 1.

6. One finds this confusion made explicit in Sellars (1956: 210-3).

7. The same basic claim can also be found in W.Sellars' early writings: "I am afraid, however, that our agreement with Lewis is more shadow than substance. For while he writes in this manner of the interpretation of the given by means of concepts whose implications transcend the given, he also holds that the sensible appearances of things do wear their hearts on their sleeves, and that we do have a cognitive vision of these hearts which is direct, unlearned, and incapable of error though we may make a slip in the expressive language by which these insights are properly formulated." (Sellars 1953: 310-1).

8. Although Lewis's epistemology has been frequently depicted as a problematic form of phenomenalism, his defenders (as well as Lewis himself) have denied this characterization. For the most recent defense of Lewis's epistemology, see Sachs 2014 (especially chapter two).

9. I am not claiming that Lewis's pragmatism and his epistemology must be interpreted as intertwined, but simply that R. W. Sellars and W. Sellars saw it this way.

10. See Kuklick (2001: 220-4). 
11. It is not clear that W. Sellars interpreted pragmatism (as embodied by anyone but Dewey) as rejecting giveness. W. Sellars recognizes Dewey's rejection of immediacy, but says little about it. See Sellars (1949: 127).

12. I say "partially" because there are numerous other issues (e.g., nominalism, meaning, naturalism, values) where one could connect $\mathrm{R}$. W. Sellars to W. Sellars. To complicate this point more, there is a large issue about reciprocal influence - one can find some evidence that W. Sellars' publications in the 1950s influenced his father's later positions. For example, see Sellars 1968.

13. See Murphey 2005.

14. Pragmatism could be separated from a particular conception of empiricism. Although W. Sellars' aim is to "correct" various aspects of pragmatism, one initially finds this argument in his father's 1932 work. See Sellars 1932 (especially: 133-4).

15. See Sellars 1953, and Sellars 1954.

16. This would be to ignore the influential role then-contemporary behaviorism plays in W. Sellars' thought. In his autobiographical reflections it is clear that W. Sellars embraced the primacy of pragmatics at the same time he developed his complicated relationship with various conceptions of behaviorism (as most notably found in the work of B. F. Skinner, Kenneth Spence, and Edwin Tolman).

17. For a longer account of this point, see Olen 2016.

18. W. Sellars' early interpretation of Carnap is discussed in Olen forthcoming.

19. See Olen 2016.

20. I take it that Misak's account straddles the fence between historical and thematic claims. Although she frequently characterizes the connection between philosophers as based on the commonality of their ideas, it seems clear that The American Pragmatists is meant to offer a historical, factual account of philosophers who fall under the banner of pragmatism.

21. This is not to suggest that critical realism and pragmatism are the only influences on W. Sellars' rejection of giveness. For a seldom discussed example see Prichard 1938.

22. Harlow 1931 is an oddly prophetic, but short, work on American realism. Harlow observes that by 1930 the influence and interest in American realism (of both the 'real' and 'critical' variety) had largely vanished.

\section{ABSTRACTS}

Although commonly cited as one of the philosophers responsible for the resurgence of interest in pragmatism, Wilfrid Sellars was also the son of Roy Wood Sellars, one of the most dedicated critical realists of the early 20th century. Given his father's realism and his own 'scientific realism,' one might assume that the history of realism - and, despite contemporary interest, not pragmatism - would best serve as the historical background for Wilfrid Sellars' philosophy. I argue that Wilfrid Sellars, far from being the adherent to classical pragmatism assumed by some, holds more in common with critical realism - specifically, a realism that was framed in opposition to pragmatism - than one finds amongst the writings of Charles Sanders Peirce, William James, or John Dewey. I support this claim by examining Wilfrid Sellars' adoption of his father's criticisms of C. I. Lewis, and offer various arguments and historical considerations 
against thematic accounts that insist on a strong connection between Wilfrid Sellars and pragmatism.

\section{AUTHOR}

\section{PETER OLEN}

Lake-Sumter State College

peterolen[at]gmail.com 